\title{
PENGARUH PENERAPAN STRATEGI QUANTUM LEARNING TERHADAP MOTIVASI BELAJAR DAN PEMAHAMAN KONSEP SISWA
}

\author{
Roni Rodiyana \\ ronirodiyana@gmail.com \\ Universitas Majalengka
}

\begin{abstract}
ABSTRAK
Penelitian ini dilaksanakan karena masalah utama yang ditemukan yaitu rendahnya motivasi siswa dan kurangnya kemampuan dalam memahami konsep pada mata pelajaran IPS khususnya di SDN Majalengka Kulon V, kemudian untuk melihat pengaruh strategi quantum learning terhadap motivasi belajar dan pemahaman konsep siswa, serta melihat ada tidaknya kendala guru dalam mengaplikasikan strategi quantum learning ini. Penelitian ini merupakan eksperimen kuasi dengan desain non equivalent control group pretest-posttest. Kelas eksperimen diberi perlakuan pembelajaran strategi quantum learning, sedangkan kelas kontrol menggunakan pembelajaran direct instructions. Penelitian ini menggunakan sampel siswa kelas V, dimana SDN Majalengka Kulon V sebagai kelas eksperimen dan SDN Tarikolot I sebagai kelas kontrol dengan masing-masing jumlah siswa yang sama yaitu sebanyak 31 siswa. Instrumen penelitian yang digunakan meliputi tes pilihan ganda, angket, lembar observasi, serta dokumentasi. Proses pembelajaran dilakukan oleh guru kelas yang sebelumnya sudah diberikan pemahaman tentang strategi quantum learning. Dari hasil analisis data di kelas eksperimen dan kelas kontrol dapat disimpulkan bahwasannya motivasi belajar dan pemahaman konsep siswa pada materi kemerdekaan di kelas eksperimen sangat baik dibandingkan dengan di kelas kontrol. Dari hasil data statistik bahwasannya strategi quantum learning sangat efesien untuk meningkatkan motivasi belajar dan meningkatkan pemahaman konsep siswa. Berdasarkan hasil penelitian di atas, sudah selayaknya seorang guru menggunakan strategi quantum learning sebagai salah satu alternatif pembelajaran untuk mengembangkan potensi peserta didik khususnya dalam mata pelajaran IPS, dalam penelitian ini penggunaan strategi quantum learning perlu dikembangkan pada materi pembelajaran yang lainnya, serta pada aspek perkembangan yang berbeda selain motivasi belajar siswa dan pemahaman konsep siswa.
\end{abstract}

Kata Kunci: quantum learning, motivasi belajar, pemahaman konsep 


\section{Pendahuluan}

Pendidikan di Indonesia semakin hari kualitasnya semakin rendah. Berdasarkan Survey United Nations Educational, Scientific and Cultural Organization (UNESCO), terhadap kualitas pendidikan di Negara-negara berkembang di Asia Pacific, Indonesia menempati peringkat 10 dari 14 negara. Sedangkan untuk kualitas para guru, kulitasnya berada pada level 14 dari 14 negara berkembang.

Salah satu permasalahan yang paling mendasar pada mutu pendidikan di Indonesia adalah rendahnya kualitas proses pembelajaran seperti metode mengajar guru yang tidak tepat, kurikulum, manajemen sekolah yang tidak efektif dan kurangnya motivasi siswa dalam belajar. Sanjaya (2010:1) mengemukakan bahwa salah satu permasalahan yang dihadapi dunia pendidikan di Indonesia adalah lemahnya proses pembelajaran. Selanjutnya dijelaskan peserta didik kurang didorong untuk mengembangkan kemampuan berpikir, karena dalam proses pembelajaran menggunakan pendekatan yang berpusat pada guru (teacher centered). Proses pembelajaran di dalam kelas diarahkan kepada kemampuan anak untuk menghafal informasi tanpa dituntut untuk memahami informasi. Sehingga siswa tidak mampu menghubungkan antara materi dengan kehidupan seharihari. Hal tersebut akan menyebabkan rendahnya motivasi belajar anak. Keller (2000: 126) mengemukakan bahwa anak akan termotivasi manakala guru mampu mendorong siswa untuk mengaitkan antara teori dengan kehidupan sehari-hari.

Begitu pula permasalahan utama yang ditemukan di kelas $\mathrm{V}$ SDN Majalengka Kulon $\mathrm{V}$ yaitu rendahnya motivasi siswa dan kurangnya kemampuan dalam memahami konsep materi kemerdekaan pada mata pelajaran IPS. Rendahnya motivasi siswa ditunjukan dengan banyaknya siswa yang mengobrol ketika pembelajaran berlangsung dan siswa terlihat kurang bersemangat. Sedangkan kurangnya kemampuan dalam memahami konsep kemerdekaan ditunjukan dengan banyak siswa yang kurang paham terhadap arti perjuangan mempertahankan kemerdekaan, siswa tidak mampu menjelaskan pertempuranpertempuran yang dilakukan dalam rangka mempertahankan kemerdekaan, siswa kurang mampu menjelaskan bagaimana caranya menghargai jasa para pahlawan.

Rendahnya pemahaman konsep yang terjadi di kelas V SDN Majalengka Kulon V, salah satunya dikarenakan konsep perjuangan mempertahankan kemerdekaan dianggap terlalu abstrak sehingga guru mengalami kesulitan dalam menyampaikan konsep tersebut supaya dapat dengan mudah dipahami secara konkrit yang dapat menarik minat siswa dalam belajar, guru masih menggunakan metode klasikal dalam arti kegiatan pembelajaran didominasi oleh guru (teacher centered) yang sesekali diikuti tanya jawab, sedangkan diakhir pembelajaran siswa diberikan tugas. Dengan demikian, siswa kurang diberi kesempatan untuk berpartisipasi aktif dalam proses pembelajaran. Kenyataannya tingkat penguasaan guru terhadap materi pembelajaran cukup baik, tetapi tidak dapat melaksanakan kegiatan pembelajaran secara optimal. Ini dikarenakan guru tersebut kurang bisa memilih dan menempatkan penggunaan strategi dalam pembelajaran IPS sehingga menyebabkan rendahnya tingkat pemahaman dan motivasi belajar siswa. Padahal, Guru memiliki peran yang sangat penting dalam memotivasi siswa supaya proses dan hasil belajarnya memperoleh hasil yang diharapkan. Motivasi belajar mempunyai kontribusi yang cukup besar terhadap keberhasilan dalam proses pembelajaran di kelas. Tanpa adanya motivasi belajar yang baik dari siswa, 
maka proses pembelajaran tidak akan berjalan efektif. Sejalan dengan hal tersebut Ngalim (2003:16) menjelaskan bahwa motivasi belajar akan memengaruhi pada prestasi belajar siswa.

Melihat pada permasalahan di atas maka, peneliti pandang perlu adanya upaya konkrit supaya siswa memiliki motivasi belajar yang tinggi dan siswa dengan mudah mampu memahami konsep khususnya dalam pembelajaran IPS. Oleh karena itu, maka upaya untuk meningkatan motivasi belajar dan pemahaman konsep siswa dalam mata pelajaran IPS diperlukan strategi pembelajaran yang inovatif, memberikan suasana yang memberdayakan dan menyenangkan, lingkungan yang mendukung dan rancangan belajar yang dinamis, fasilitas yang luwes dan keterampilan belajar. Salah satu strategi pembelajaran yang dapat digunakan sebagai solusi untuk meningkatkan motivasi belajar dan pemahaman konsep siswa yaitu dengan penggunaan strategi quantum learning.

Quantum learning merupakan orkestra dari berbagai interaksi yang ada di dalam dan disekitar aktivitas belajar. Interaksi-interaksi ini mencakup unsurunsur belajar efektif yang mempengaruhi kesuksesan siswa. Interaksi-interaksi ini mengubah kemampuan dan bakat alamiah siswa menjadi sesuatu yang akan bemanfaat bagi dirinya dan orang di sekitarnya. Sehingga menurut DePorter quantum learning mampu meningkatkan motivasi belajar siswa. Sejalan dengan itu, menurut Purwanto (1999: 29) menjelaskan bahwa motivasi belajar akan mempengaruhi pada hasil belajar siswa. Hal ini dapat didefinisikan bahwa apabila siswa sudah memiliki motivasi belajar yang tinggi, maka hasil belajarnya pun akan tinggi.

Tujuan yang ingin dicapai dalam penelitian ini yaitu untuk mengetahui pengaruh strategi quantum learning terhadap motivasi belajar dan pemahaman konsep siswa pada materi kemerdekaan di kelas V Sekolah Dasar dalam mata pelajaran Ilmu Pengetahuan Sosial.

\section{Strategi Quantum Learning}

Menurut Sanjaya, (2010: 126) dalam dunia pendidikan, strategi diartikan sebagai perencanaan yang berisi tentang rangkaian kegiatan yang didesain untuk mencapai tujuan pendidikan tertentu. Sedangkan Kemp (1994: 87) menjelaskan bahwa strategi pembelajaran adalah suatu kegiatan pembelajaran yang harus dikerjakan guru dan siswa agar tujuan pembelajaran dapat dicapai secara efektif dan efisien. Dari pendapat tersebut, Dick and Carey (1985: 102) juga menyebutkan bahwa strategi pembelajaran itu adalah suatu set materi dan prosedur pembelajaran yang digunakan secara bersama-sama untuk menimbulkan hasil belajar pada siswa.

Jadi strategi pembelajaran sifatnya
masih konseptual dan untuk
mengimplementasikannya digunakan
berbagai metode pembelajaran tertentu, dengan kata lain, strategi merupakan $a$ plan of operation achieving something Sanjaya (2010: 127). Newman dan Logan (dalam Syamsudin, 2003: 97) mengemukakan empat unsur strategi dari setiap usaha, yaitu:

a. Mengidentifikasi dan menetapkan spesifikasi dan kualifikasi hasil dan sasaran yang harus dicapai, dengan mempertimbangkan aspirasi dan selera masyarakat yang memerlukannya.

b. Mempertimbangkan dan memilih jalan pendekatan utama yang paling efektif untuk mencapai sasaran.

c. Mempertimbangkan dan menetapkan langkah-langkah yang akan dtempuh sejak titik awal sampai dengan sasaran.

d. Mempertimbangkan dan menetapkan tolak ukur (criteria) dan patokan ukuran (standard) untuk mengukur 
dan menilai taraf keberhasilan (achievement) usaha.

Strategi quantum learning bermula dari pembelajaran yang memberikan sugesti (suggestology) yang berakar dari eksperimen yang dilakukan Dr. Georgi Lozanov kemudian dipopulerkan oleh Bobby DePorter. DePorter (2002: 14) mengatakan bahwa suggestology adalah pemercepatan belajar yang didefinisikan sebagai "memungkinkan siswa untuk belajar dengan kecepatan yang mengesankan, dengan upaya yang normal, dan dibarengi kegembiraan".

Selain itu ada pula prinsip motivasi AMBAK (Apa Manfaatnya Bagiku). AMBAK adalah motivasi yang didapat dari pemilihan secara mental antara manfaat dan akibat-akibat suatu keputusan. Dengan AMBAK dapat menciptakan minat yang ampuh untuk belajar (DePorter, 2000: 49). AMBAK dapat diartikan sebagai keterkaitan antara materi dengan kehidupan sehari-hari, sehingga siswa akan termotivasi.

Adapun sintaks atau langkah penerapan strategi pembelajaran kuantum (quantum learning) yang dikenal dengan sebutan TANDUR DePorter,et al.,(2005: 10) adalah sebagai berikut:

a. Tumbuhkan, tumbuhkan minat dengan memuaskan "Apakah Manfaatnya BagiKu” (AMBAK), dan manfaatkan kehidupan belajar.

b. Alami, ciptakan atau datangkan pengalaman umum yang dapat dimengerti semua pelajar.

c. Namai, sediakan kata kunci, konsep, model, rumus, strategi, dan sebuah masukan.

d. Demonstrasikan, sediakan kesempatan bagi pelajar untuk menunjukkan bahwa mereka tahu.

e. Ulangi, tunjukkan pelajar cara-cara mengulang materi dan menegaskan, "Aku tahu bahwa aku memang tahu ini”.
f. Rayakan, Pengakuan untuk penyelesaian, partisipasi, dan pemerolehan keterampilan dan ilmu pengetahuan.

\section{Motivasi Belajar}

Menurut Dirgagunarsa (1978: 92), motif adalah dorongan atau kehendak menjadi yang menyebabkan timbulnya semacam kekuatan agar seseorang berbuat atau bertindak, dengan perkataan lain bertingkah laku karena tingkah laku tersebut dilatar belakangi oleh adanya motif, maka disebut tingkah laku bermotivasi.

Selanjutnya pengertian motivasi menurut Mc. Donald (dalam Sardiman, 2009: 73) adalah perubahan energi dalam diri seseorang yang ditandai dengan munculnya "feeling" dan didahului dengan tanggapan terhadap adanya tujuan. Kemudian motivasi menurut Purwanto (1990: 71) adalah pendorongan, yaitu suatu usaha yang disadari untuk mempengaruhi tingkah laku seseorang agar tergerak hatinya untuk bertindak melakukan sesuatu sehingga mencapai hasil atau tujuan tertentu.

Selanjutnya Djamarah (2002: 115), sangat percaya bahwa tingkah laku manusia dibangkitkan dan diarahkan oleh kebutuhan-kebutuhan tertentu, seperti kebutuhan fisiologis, rasa aman, rasa cinta, penghargaan aktualisasi diri, mengetahui dan mengerti, dan kebutuhan estetik. Sehubungan hal tersebut Sardiman (2001: 85) menjelaskan ada tiga fungsi motivasi antara lain:

a. Mendorong manusia untuk berbuat, jadi sebagai penggerak atau motor yang melepaskan energi. Motivasi dalam hal ini merupakan motor penggerak dari setiap kegiatan yang akan dikerjakan.

b. Menentukan arah perbuatan, yakni kearah tujuan yang hendak dicapai. Dengan demikin motivasi dapat memberikan arah dan kegiatan yang 
harus dikerjakan sesuai dengan rumusan tujuannya.

c. Menyeleksi perbuatan, yakni menentukan perbuatan-perbuatan apa yang harus dikerjakan yang serasi guna mencapai tujuan, dengan menyisihkan perbuatan-perbuatan yang tidak bermanfaat bagi tujuan tersebut.

Menurut Rusyan (2005: 121), pada garis besarnya motivasi mengandung nilai-nilai sebagai berikut: motivasi menentukan tingkat keberhasilan atau kegagalan perbuatan belajar siswa; pengajaran yang bermotivasi pada hakekatnya adalah pengajaran yang disesuaikan dengan kebutuhan, dorongan, motif dan minat yang ada pada siswa; pengajaran yang bermotivasi menurut kreatifitas dan imajinitas pada guru untuk berusaha secara sungguh-sungguh mencari cara-cara yang relevan dan serasi guna membangkitkan dan memelihara motivasi belajar pada siswa; berhasil atau tidaknya dalam menumbuhkan dan menggunakan motivasi dalam pengajaran erat kaitannya dengan pengaturan dalam kelas; asas motivasi menjadi salah satu bagian yang integral dari asas-asas mengajar.

\section{Pemahaman Konsep}

Pemahaman konsep berasal dari dua kata, pemahaman dan konsep. Pengertian pemahaman dikemukakan oleh Winkel dan Mukhtar (dalam Sudaryono, 2012: 44) mengemukakan bahwa: pemahaman yaitu kemampuan seseorang untuk mengerti atau memahami sesuatu setelah sesuatu itu diketahui atau diingat, mencakup kemampuan untuk menangkap makna dari arti bahan yang dipelajari, yang dinyatakan dengan menguraikan isi pokok dari suatu bacaan, atau mengubah data yang disajikan dalam bentuk tertentu ke bentuk yang lain.

Bloom dalam bukunya yang berjudul "Handbook on formative and sumative evaluation of student learning" (1979: 90-104) menyatakan bahwa: "Comprehension that is when students are confronted with a communication, they are expected to know what is being communicated and to be able to make some use of the material or ideas contained in it. The communication may be in oral or written form, in verbal or symbolic form." Sejalan dengan pernyataan Bloom di atas, Subiyanto (1988: 49) menyatakan bahwa pemahaman bersangkutan dengan intisari dari sesuatu, yaitu suatu bentuk pengertian yang menyebabkan seseorang mengetahui apa yang sedang dikomunikasikan.

Sementara pengertian konsep yang dikemukakan oleh Sapriya (2009: 43) adalah pengabstraksian dari sejumlah benda yang memiliki karakteristik yang sama, konsep merupakan abstraksi, kontruksi logis yang terbentuk dari kesan, tanggapan dan pengalaman kompleks. Parreren (dalam Winkel, 1996: 76) memberi batasan bahwa konsep adalah satuan arti yang mewakili sejumlah objek yang memiliki ciri-ciri yang sama. Begitu pula menurut Bloom dalam Vestari (2009: 16) pemahaman konsep adalah kemampuan menangkap pengertianpengertian seperti mampu mengungkap suatu materi yang disajikan kedalam bentuk yang lebih dipahami, mampu memberikan interpretasi dan mampu mengaplikasikannya.

Selanjutnya menurut Sanjaya (2009: 88) mengemukakan pemahaman konsep adalah kemampuan siswa yang berupa penguasaan sejumlah materi pelajaran, tetapi mampu mengungkapkan kembali dalam bentuk lain yang mudah dimengerti, memberikan interprestasi data dan mampu mengaplikasi konsep yang sesuai dengan struktur kognitif yang dimilikinya.

Bloom (1979: 89) membagi pemahaman menjadi tiga aspek, yaitu translasi (translation), interpretasi 
(interpretation), dan ekstrapolasi (extrapolation).

Pemahaman translasi (kemampuan menterjemahkan) menurut Subiyanto (1988: 49) adalah kemampuan dalam memahami suatu gagasan yang dinyatakan dengan cara lain dari pernyataan asal yang dikenal sebelumnya. Bloom (1979: 92) mengemukakan indikator pencapaian kemampuan translasi sebagai berikut: The ability to translate a problem given in technical or abstract phraseology into concrete or less abstract phraseology. The ability to translate relationships expressed in symbolic form, including illustrations, maps, tables, diagrams, graphs, and mathematical and other formulas, to verbal form or vice versa. Pemahaman interpretasi (kemampuan menafsirkan) menurut Subiyanto (1988: 49) adalah kemampuan untuk memahami bahan atau ide yang direkam, diubah, atau disusun dalam bentuk lain. Pemahaman ekstrapolasi (kemampuan meramalkan) menurut Subiyanto (1988: 49) adalah kemampuan untuk meramalkan kecenderungan yang ada menurut data tertentu dengan mengutarakan konsekuensi dan implikasi yang sejalan dengan kondisi yang digambarkan.

Menurut Kardiyono (1980: 13) guru dalam memilih konsep yang akan diberikan kepada siswa hendaknya mendasarkan pada prinsip-prinsip keperluan, ketepatan, mudah dipelajari, dan kegunaan.

\section{Metode dan Desain Penelitian}

Desain penelitian yang digunakan dalam penelitian ini adalah menggunakan metode eksperimen kuasi. Metode ini digunakan untuk mengetahui pengaruh motivasi belajar dan pemahaman konsep siswa sekolah dasar antara yang mendapat pembelajaran dengan strategi pembelajaran quantum learning dengan siswa yang mendapat pembelajaran dengan strategi pembelajaran yang biasa dipakai oleh guru kelas di sekolah tersebut. Guru kelas tersebut biasa memakai strategi pembelajaran direct instruction.

Penelitian eksperimen kuasi yang akan dilaksanakan yaitu dengan bentuk nonequivalent (pretest and posttest) control group design yang mengacu pendapat Fraenkel dan Wallen (2007: 278). Dimana dilakukan tes awal (pretest) terhadap kedua kelompok tersebut berupa soal tes. Pada kelas eksperimen diberi perlakuan dengan penggunaan strategi quantum learning dan pada kelas kontrol dengan pembelajaran non quantum learning yaitu direct intruction. Setelah kedua kelompok mendapat perlakuan dalam pembelajaran, maka diakhiri dengan pemberian tes akhir (post test) terhadap kedua kelompok siswa itu berupa angket dan soal tes. Perangkat soal tes awal dan tes akhir menggunakan perangkat tes yang sama. Adapun bagan desain untuk penelitian ini adalah sebagai berikut:

Desain Penelitian

\begin{tabular}{|c|c|c|c|}
\hline Kelompok & $\begin{array}{c}\text { Observasi } \\
\text { Awal }\end{array}$ & Perlakuan & $\begin{array}{c}\text { Observasi } \\
\text { Akhir }\end{array}$ \\
\hline Eksperimen & $\mathrm{O}_{1}$ & $\mathrm{X}_{1}$ & $\mathrm{O}_{2}$ \\
\hline Kontrol & $\mathrm{O}_{1}$ & $\mathrm{X}_{2}$ & $\mathrm{O}_{2}$ \\
\hline
\end{tabular}

Keterangan:

$\mathrm{O}_{1}=$ Pretest

$\mathrm{O}_{2}=$ Posttest

$\mathrm{X}_{1}=$ pembelajaran menggunakan strategi pembelajaran quantum learning.

$\mathrm{X}_{2}=$ pembelajaran menggunakan pembelajaran direct intruction.

\section{Analisis Data}

Analisis data dilakukan untuk menjawab rumusan masalah dan pengujian hipotesis. Data yang diperoleh berupa nilai hasil pretes dan postest pada kelas eksperimen dan kelas kontrol akan dianalisis dengan menggunakan perhitungan uji statistik. Data kuantitatif diperoleh dari hasil pretest dan postest 
yang memuat indikator motivasi belajar dan pemahaman konsep siswa.

1. Uji Normalitas Data

Uji normalitas dilakukan untuk mengetahui apakah data berdistribusi normal atau tidak. Hipotesis yang digunakan untuk mengetahui normalitas data adalah sebagai berikut:

$\mathrm{H}_{0}$ : Data berditribusi normal

$\mathrm{H}_{1}$ : Data tidak berdistribusi normal

Untuk menghitung normalitas suatu data akan dilakukan dengan uji shapirowilk, karena data yang diteliti dalam penelitian ini berjumlah 31 siswa. Kriteria pengujiannya adalah sebagai berikut:

Jika sig $<\propto$ dengan $\propto=0,05$, maka

$\mathrm{H}_{0}$ ditolak.

Jika sig $\geq \propto$ dengan $\propto=0,05$, maka $\mathrm{H}_{0}$ diterima.

Dengan $P$-value adalah nilai signifikansi hasil perhitungan

(Trihendradi, 2012: 94).

\section{Uji Homogenitas}

Pengujian homogenitas varians dialkukan antara kelompok eksperimen (SDN Majalengka Kulon V) dan kontrol (SDN Tarikolot I), dan antara kelompok pretest dan posttest dalam satu kelompok eksperimen atau kontrol. Hal ini dilakukan dengan tujuan untuk mengetahui apakah varians kedua kelompok sama atau berbeda. Hipotesis yang digunakan untuk menghitung homogenitas suatu data adalah sebagai berikut:

$\mathrm{H}_{0}$ : Varians kedua kelompok sampel homogen.

$\mathrm{H}_{1}$ : Varians kedua kelompok sampel tidak homogen.

Untuk menghitung homogenitas suatu data akan dilakukan dengan uji Lavene. Kriteria pengujiannya adalah sebagai berikut:

Jika sig $<\propto$ dengan $\propto=0,05$, maka

$\mathrm{H}_{0}$ ditolak.
Jika sig $\geq \propto$ dengan $\propto=0,05$, maka $\mathrm{H}_{0}$ diterima.

Dengan P-value adalah nilai signifikansi hasil perhitungan (Trihendradi, 2012: 136).

\section{Uji Perbedaan Dua Rata-rata}

Apabila sebaran data berdistribusi normal dan varians kedua kelompok sampel homogen, maka uji perbedaan rata-rata menggunakan uji $\mathrm{t}$ dengan rumus:

$$
t=\frac{\bar{X}_{1}-\bar{X}_{2}}{\sqrt[s]{\frac{1}{n_{1}}+\frac{1}{n_{2}}}}
$$

Apabila sebaran data berdistribusi tidak normal, maka uji perbedaan rata-rata menggunakan statistik non parametrik dengan uji Mann-Whitney. Hipotesis yang digunakan untuk mengetahui perbedaan rata-rata suatu kelompok data adalah sebagai berikut:

$\mathrm{H}_{0}$ : Tidak terdapat perbedaan ratarata antara kelas eksperimen dan kelas kontrol.

$\mathrm{H}_{1}$ : Kelas eksperimen lebih baik dari kelas kontrol.

Untuk menghitung perbedaan ratarata data akan dilakukan dengan menggunakan uji $\mathrm{t}$ atau Man-Whitney tergantung distribusi data dan varians kedua kelompok sampel. Pengujiannya adalah sebagai berikut:

Jika sig $<\propto$ dengan $\propto=0,05$, maka $\mathrm{H}_{0}$ ditolak.

Jika sig $\geq \propto$ dengan $\propto=0,05$, maka $\mathrm{H}_{0}$ diterima.

Dengan $P$-value adalah nilai signifikansi hasil perhitungan (Trihendradi, 2012: 125). 


\section{Hasil Penelitian dan Pembahasan}

Sebelum melakukan perlakuan terhadap kelas kontrol dan kelas eksperimen, peneliti menelaah mengenai kondisi awal peserta didik terlebih dahulu. Data diperoleh dari nilai rata-rata hasil ulangan harian terakhir pada mata pelajaran IPS. Dari data tersebut diperoleh 31 siswa SDN Majalengka Kulon V terdapat $64 \%$ siswa yang memeroleh nilai di atas KKM, 36\% siswa memeroleh nilai di bawah KKM. Sedangkan, di SDN Tarikolot I terdapat $60 \%$ siswa yang memeroleh nilai di atas KKM, dan $40 \%$ siswa memeroleh di bawah KKM.

Setelah diketahui data tersebut dapat disimpulkan bahwa kemampuan awal peserta didik antara kelas kontrol dengan kelas eksperimen relatif sama. Langkah selanjutnya yaitu melakukan uji coba soal dan angket untuk mengukur validitas dan reliabilitas soal tersebut. Dari hasil pengukuran tersebut diperoleh 20 soal pemahaman konsep yang valid dan reliabel dari 30 soal. Berikutnya yaitu melaksanakan penelitian diawali dengan memberikan pretest untuk mengetahui kemampuan peserta didik mengenai motivasi dan pemahaman konsep yang mereka miliki sebelum diberikan perlakuan. Adapun tahapan penelitian secara rinci dijabarkan sebagai berikut.

\section{Pengaruh Strategi Quantum Learning} Terhadap Motivasi Belajar Siswa Sekolah Dasar

Data hasil penelitian diperoleh dengan cara memberikan tes awal (pretest) dan tes akhir (postest) kepada siswa. Selanjutnya dilakukan pengolahan dan analisis data tes awal (pretest), tes akhir (postest) serta uji beda rata-rata atau (uji $t$ ) motivasi belajar siswa. Dimana rata-rata pretest motivasi belajar siswa di kelas kontrol yaitu sebesar 64,61 dan rata-rata postest 75,74 . Kemudian skor rata-rata pretest motivasi belajar pada kelas eksperimen yaitu sebesar 65,90 dan ratarata postest 80,13 . Hal ini menunjukan bahwa motivasi belajar di kelas kontrol dan di kelas eksperimen jauh berbeda. Hasil di kelas kontrol setelah dilakukan postest meningkat namun relatif kecil yaitu sebesar 11,13, sedangkan pada kelas eksperimen hasilnya sangat meningkat yaitu sebesar 14,23. Selanjutnya postest motivasi belajar siswa antara kelompok kelas kontrol dan kelompok kelas eksperimen terdapat selisih rata-rata skor sebesar 3,10. Hal ini berarti pembelajaran di kelas kontrol yang menggunakan direct instructions kurang meningkatkan motivasi belajar secara signifikan, sedangkan penggunaan quantum learning yaitu di kelas eksperimen dapat meningkatkan motivasi belajar siswa, dimana terdapat selisih skor rata-rata 3,10 antara kelompok kelas kontrol dan kelompok kelas eksperimen.

Selain itu uji statistik menggunakan program SPSS 21 pun dilakukan, yaitu dilakukan uji perbedaan dua rata-rata (uji t) terhadap motivasi belajar pada kedua kelas. Hasil pengujian normalitas dan homogenitas data, menunjukkan bahwa data kedua kelas berdistribusi normal dan memiliki varians yang homogen. Sehingga analisis selanjutnya dalam melakukan uji perbedaan meggunakan statistik parametrik, yaitu $t$ indepentdent sample. Hasil uji t indepentdent sample diperoleh nilai signifikansi sebesar 0,004, lebih kecil dari $\propto=0,05$, maka $\mathrm{H}_{1}$ diterima. Hal tersebut berarti bahwa pada tingkat kepercayaan 95\%, motivasi belajar siswa yang mendapatkan quantum learning lebih baik daripada siswa yang mendapatkan pembelajaran direct instructions.

Hal ini bisa dipahami bahwa dengan quantum learning anak mampu mengembangkan motivasi belajarnya, karena quantum learning sebagai salah satu strategi pembelajaran yang dapat menciptakan suasana pembelajaran yang efektif, menggairahkan, dan 
menyenangkan (Kaifa, 1999: 72). Strategi pembelajaran kuantum merupakan bentuk inovasi pengubahan bermacam-macam interaksi yang ada di dalam dan di sekitar momen belajar, sehingga secara tidak langsung akan mempengaruhi motivasi internal belajar anak. Berdasarkan penjelasan di atas dapat disimpulkan bahwa strategi quantum learning dapat diterapkan sebagai salah satu strategi yang dapat membantu meningkatkan motivasi belajar anak yang dibuktikan dengan hasil pengamatan langsung dimana anak yang kurang motivasi dalam pembelajaran, mereka menjadi antusias, terlihat bertanggung jawab terhadap kegiatankegiatan yang dilakukannya, serta aktif dalam menjawab dan mengemukakan pendapatnya masing-masing.

\section{Pengaruh Strategi Quantum Learning} terhadap Pemahaman Konsep Siswa Sekolah Dasar

Penelitian ini juga bertujuan untuk mengetahui pemahaman konsep siswa yang mendapatkan pembelajaran dengan quantum learning dan siswa yang mendapat pembelajaran direct instructions. Untuk tujuan penelitian tersebut, peneliti memperoleh data juga dengan cara memberikan pretest dan postest kepada siswa. Selanjutnya dilakukan pengolahan dan analisis data pretest, postest dan uji-t pemahaman konsep siswa. Analisis mengenai skor pretest pada kedua kelas menunjukkan tidak terdapat perbedaan yang signifikan. Namun demikian secara deskriptif, ratarata skor pretest siswa kelas eksperimen lebih tinggi daripada kelas kontrol.

Dari hasil penelitian dimana ratarata pretest pemahaman konsep siswa di kelas kontrol yaitu sebesar 64,35 dan ratarata postest 72,42 . Kemudian skor ratarata pretest motivasi belajar pada kelas eksperimen yaitu sebesar 66,29 dan ratarata postest 83,71 . Hal ini menunjukan bahwa motivasi belajar di kelas kontrol dan di kelas eksperimen jauh berbeda. Hasil di kelas kontrol setelah dilakukan postest meningkat namun relatif kecil yaitu sebesar 8,06, sedangkan pada kelas eksperimen hasilnya sangat meningkat yaitu sebesar 17,42. Selanjutnya postest motivasi belajar siswa antara kelompok kelas kontrol dan kelompok kelas eksperimen terdapat selisih rata-rata skor sebesar 9,35. Hal ini berarti pembelajaran di kelas kontrol yang menggunakan direct instructions kurang meningkatkan pemahaman konsep siswa secara signifikan, sedangkan penggunaan quantum learning yaitu di kelas eksperimen dapat meningkatkan pemahaman konsep siswa, dimana terdapat selisih skor rata-rata 9,35 antara kelompok kelas kontrol dan kelompok kelas eksperimen.

Selain itu uji statistik menggunakan program SPSS 21 pun dilakukan, yaitu dilakukan uji perbedaan dua rata-rata (uji t) terhadap motivasi belajar pada kedua kelas. Hasil pengujian normalitas dan homogenitas data, menunjukkan bahwa data kedua kelas berdistribusi normal dan memiliki varians yang homogen. Sehingga analisis selanjutnya dalam melakukan uji perbedaan meggunakan statistik parametrik, yaitu $t$ indepentdent sample. Hasil uji t indepentdent sample diperoleh nilai signifikansi sebesar 0,000 , lebih kecil dari $\propto=0,05$, maka $\mathrm{H}_{1}$ diterima. Hal tersebut berarti bahwa pada tingkat kepercayaan 95\%, pemahaman konsep siswa yang mendapatkan quantum learning lebih baik daripada siswa yang mendapatkan pembelajaran direct instructions.

Strategi quantum learning terhadap pemahaman konsep siswa sekolah dasar di kelas V sangat baik dan efesien sekali. Hal ini terlihat dari aktifitas siswa yang mampu menangkap informasi dengan cermat, menginterpretasi dan mengaplikasikan materi yang disajikan oleh gurunya. Hal tadi sejalan dengan 
Sanjaya (2009: 88) mengemukakan bahwa pemahaman konsep siswa berupa penguasaan sejumlah materi pelajaran, mampu mengungkapkan kembali dalam bentuk lain yang mudah dimengerti, memberikan interprestasi data dan mampu mengaplikasi konsep yang sesuai dengan struktur kognitif yang dimilikinya.

3. Kendala Guru dalam Mengaplikasikan Strategi Quantum Learning di Kelas V Sekolah Dasar

Pembelajaran kuantum dapat dikatakan sebagai strategi pembelajaran yang menekankan untuk memberikan manfaat yang bermakna dan juga menekankan pada tingkat kesenangan dari peserta didik atau siswa. Bukan hanya itu, Bobbi de Porter mengatakan bahwa quantum learning adalah kiat, petunjuk, strategi dan seluruh proses belajar yang dapat mempertajam pemahaman dan daya ingat, serta membuat belajar sebagai suatu proses yang menyenangkan dan bermanfaat (DePorter, 2005: 12). Mengapa demikian, karena quantum learning dirancang menjadi sebuah orkestra sehingga proses pembelajaran menjadi bermakna dan menyenangkan.

Oleh karena itu, dalam proses pembelajaran dengan menggunakan strategi quantum learning diperlukan seorang guru yang luwes, memiliki pengalaman yang nyata dan mampu mengelola kelas. Mengelola kelas dalam arti menciptakan lingkungan yang kondusif yaitu cara guru dalam menata ruang kelas, pencahayaan warna, pengaturan meja dan kursi, tanaman, musik, mengkondisikan siswa dan semua hal yang mendukung proses belajar.

Namun berdasarkan hasil wawancara yang diperoleh, guru baru pertama kali menggunakan strategi quantum learning maka, pada pertemuan pertama dalam penelitian ini guru model mengalami kesulitan dalam hal mengajak peserta didik pada proses pembelajaran yang berbeda dari biasanya, menumbuhkan motivasi siswa dan kesulitan dalam mengidentifikasi karakter setiap peserta didik. Karena strategi quantum learning mengarahkan seorang guru menjadi guru yang "baik", baik dalam arti bahwa guru memiliki ide-ide kreatif dalam memberikan proses pembelajaran, mengetahui dengan baik tingkat kemampuan siswa. Sejalan dengan hal tersebut menurut DePorter \& Hernacki (2005: 25) pembelajaran kuantum harus menyesuaikan kemampuan otak dengan apa yang dibutuhkan oleh otak, sehingga tujuan pembelajaran dapat tercapai dengan mudah.

Pada pertemuan kedua, kondisi pembelajaran sudah mengalami perubahan dari pertemuan pertama. Perubahan baik dari guru maupun peserta didik. Guru sudah mulai bisa memotivasi peserta didik dengan total. Mereka menikmati suasana yang diciptakan. Kemudian di pertemuan ketiga sudah tidak ada lagi kekakuan baik guru maupun siswa. Siswa sudah terlihat banyak yang mengeluarkan ide kreatifnya. Mereka membuat yel-yel dengan kreatifitas masing-masing kelompoknya.

Dari hasil observasi diperoleh data bahwa guru model melaksanakan seluruh rangkaian pada tahapan quantum learning yang dirangkum dalam TANDUR (tumbuhkan, alami, namai, demonstrasikan, ulangim rayakan). Tahapan tersebut dimulai dari menumbuhkan minat belajar dengan menggunakan metode sugesti dan mengaitkan materi dengan kehidupan sehari-hari, selanjutnya siswa menonton film mengenai kemerdekaan, siswa menceritakan kembali film yang sudah ditontong secara berkelompok, siswa mendemostrasikan hasil diskusi mengenai perang setelah kemerdekaan, siswa menyimpulkan materi yang telah dipelajari, kemudian langkah terakhir adalah memberikan apresiasi terhadap siswa yang belajar dengan sungguh- 
sungguh serta membuat yel-yel sebagai perayaan bahwa pembelajaran telah berhasil dilaksanakan dengan baik.

\section{Simpulan}

Berdasarkan penelitian dan pengolahan data dari hasil penelitian yang dilakukan, maka dapat ditarik kesimpulan sebagai berikut:

1. Strategi quantum learning terhadap motivasi belajar siswa memiliki pengaruh yang sangat signifikan jika dibandingkan dengan menggunakan pembelajaran direct instructions, hal ini terlihat dari hasil uji $\mathrm{t}$ indepentdent sample diperoleh nilai signifikansi sebesar 0,004, lebih kecil dari $\propto=0,05$. Hal tersebut berarti bahwa pada tingkat kepercayaan 95\%, motivasi belajar siswa yang mendapatkan quantum learning lebih baik daripada siswa yang mendapatkan pembelajaran direct instructions.

2. Strategi quantum learning terhadap pemahaman konsep siswa memiliki pengaruh yang sangat signifikan dibandingkan dengan pembelajaran direct instructions pada kelas kontrol, hal ini terlihat dari hasil uji $t$ indepentdent sample diperoleh nilai signifikansi sebesar 0,000, lebih kecil dari $\propto=0,05$. Hal tersebut berarti bahwa pada tingkat kepercayaan $95 \%$, pemahaman konsep siswa yang mendapatkan quantum learning lebih baik daripada siswa yang mendapatkan pembelajaran direct instructions, hal ini dikarenakan rangkaian kegiatan pembelajaran yang menekankankan pada proses berpikir yang tenang, nyaman dan menyenangkan.

3. Kendala guru dalam mengaplikasikan strategi quantum learning yaitu dalam proses pembelajaran dengan menggunakan strategi quantum learning diperlukan seorang guru yang luwes, memiliki pengalaman yang nyata dan mampu mengelola kelas.
Mengelola kelas dalam arti menciptakan lingkungan yang kondusif yaitu cara guru dalam menata ruang kelas, pencahayaan warna, pengaturan meja dan kursi, tanaman, musik, mengkondisikan siswa dan semua hal yang mendukung proses belajar. Guru model mengalami kesulitan dalam hal mengajak peserta didik pada proses pembelajaran yang berbeda dari biasanya, menumbuhkan motivasi siswa dan kesulitan dalam mengidentifikasi karakter setiap peserta didik.

\section{Daftar Pustaka}

Arikunto, Suharsimi. (2006). Prosedur Penelitian Suatu Pendekatan Praktik. Jakarta: Rineka Cipta.

Bloom, Benyamin S. (1979). Taksonomy of Educational Objectives (The Clasification of Educational Goals) Handbook 1 Cognitive. Domain. London: Longman.

DePorter and Mark Reardon. (2005). Quantum Teaching. Bandung : Mizan Media Utama.

DePorter and Mike Henarcki. (2002). Quantum Learning. Jakarta: Gramedia.

(2010). Quantum Learning. Bandung: Kaifa.

Learning.

Quantum

Bandung: Kaifa.

Dick, Walter \& Carey Lou. (1985). The Systematic Design of Intruction. London: Scott, Foresman and Company. 
Dirgagunarsa, Singgih. (1978). Pengantar Psikologi. Jakarta: Mutiara.

Djamarah, B, S. (2002). Psikologi Belajar. Jakarta: Rineka Cipta.

Fraenkel, J.R. dan Wallen, N.E. (2007). How to Design and Evaluate Research in Education 3th Edition. Singapore McGraw-Hill, INC.

Kardiyono. (1980). Mengajar Konsep Ilmu Pengetahuan Sosial. Jakarta: P3G Departemen P dan K.

Kemp, J. E. (1994). Proses Perancangan Pengajaran. Bandung: Penerbit ITB.

Keller, John. (2000). How to Integrate Learner Motivation Planning into Lesson Planning: The ARCS Model Approach. [online]. Tersedia: http://www.arcsmodel.com $\quad[15$ Desember 2014]. (1987). Development and Use of The ARCS Model Of Instructional Design. Jurnal of Instructional Development.

Purwanto, Ngalim. (2003). Psikologi Pendidikan. Bandung: Remaja Rosadakarya.

(1999). Psikologi Pendidikan. Bandung: Remaja Rosadakarya.

Rusyan, T, A. (2005). Motivasi Kerja. Jakarta: PT. Gramedia Indonesia.

Sanjaya, Wina. (2010). Strategi Pembelajaran Berorientasi Standar Proses Pendidikan. Jakarta: Pranada Media Group.

(2009). Strategi Pembelajaran Berorientasi Standar
Proses Pendidikan. Jakarta: Prenada.

(2008). Strategi

Pembelajaran Berorientasi Standar Proses Pendidikan. Jakarta: Prenada.

Sapriya. (2009). Pendidikan IPS Konsep dan Pembelajaran. Bandung: PT. Rosdakarya.

Sardiman. (2001). Interaksi dan Motivasi Belajar Mengajar. Jakarta: Rajawali pers.

. (2009). Interaksi dan Motivasi Belajar Mengajar. Jakarta: Rajawali pers.

. (2001). Interaksi dan Motivasi Belajar Mengajar. Jakarta: Grafindo Persada.

Subiyanto. (1988). Evaluasi Pendidikan dan Pengetahuan Alam. DEPDIKBUD.

Sudaryono. (2012). Dasar-Dasar Evaluasi Pembelajaran. Yogyakarta. Graha.

Syamsudin, Abin. (2003). Psikologi Pendidikan. Bandung: Rosda Karya Remaja.

Taniredja, Tukiran, dkk. (2012). ModelModel Pembelajaran Inovatif. Bandung: Alfabeta.

Trihendradi, C. (2012). Step by Step SPSS 20 Analisis Data Statistik. Yogyakarta: Penerbit Andi.

Vestari, D. (2009). Model Pembelajaran Berbasis Fenomena dengan Pendekatan Inkuiri Terbimbing untuk Meningkatkan Pemahaman Konsep Pembiasan Cahaya dan Keterampilan Generik Sains 
Siswa SMP. SPS: Universitas

Pendidikan Indonesia: Bandung.

Wingkel, W. S. (1996). Psikologi

Pengajaran. Jakarta: Grasindo.

. (1987). Psikologi pembelajaran.

Jakarta: Gramedia. 